\title{
特集 頭蓋底静脈の基礎と臨床（2）：錐体斜台部
}

\section{Petroclival Region Tumor の手術と静脈}

$\begin{array}{llllll}\text { 松島 俊夫 } & \text { 増 岡 淳 河 島 雅 到 } \\ \text { 井上 浩 平 峯 田寿 裕 } & & \end{array}$

\author{
Petroclival Region Tumor Surgery and the Related Veins \\ by \\ Toshio Matsushima, M. D., Jun Masuoka, M. D., Masatou Kawashima, M. D., \\ Kouhei Inoue, M. D., and Toshiyuki Mineta, M. D. \\ from \\ Department of Neurosurgery, Faculty of Medicine, Saga University
}

\begin{abstract}
Surgery for petroclival region tumors is one of the most difficult surgeries because the tumors are located in the deep midline area and furthermore, they are often situated in both the supra- and the infratentorial areas. We have used the posterior transpetrosal approach (PTA) or the lateral suboccipital approach (LSA), depending on the location of the main mass in each case. However, we now use the LSA more frequently after experiencing a certain amount of cases. This is because when using this approach the anatomy of the intraoperative view can be easily understood and it requires less time to expose the tumor. The LSA for petroclival tumor surgery means the infratentorial lateral supracerebellar approach, and the transtentorial approach can be added from the inferior side, if necessary. The main obstacles for the approach include the superior petrosal veins. Surgeons should know well the anatomy of the veins. In the case of the PTA, the superior petrosal veins are not a big problem but the vein of Labbé, temporal bridging veins, bridging veins to the tentorial edge and tentorial sinuses are obstacles.

Herein, we describe the basic procedures and techniques of the LSA and the PTA and then, we explain the surgical anatomy of the deep venous system near the tentorial edge and the methods for dealing with the veins, especially the superior petrosal vein.
\end{abstract}

(Received July 9, 2008; accepted July 14, 2008)

Key words : petroclival region, tumor surgery, surgical approach, deep venous system, complication Jpn J Neurosurg (Tokyo) $17: 761-772,2008$

\section{はじめに}

Petroclival region（錐体斜台部）は正中深部に存在する ため, 到達困難で, 手術が最も難しい場所の一つである. この部の腫瘍性病変は小脳テント上下にまたがって存在 することもしばしばであり，時として手術アプローチの 選択やどの程度摘出すべきかで悩むこともあるし，部分
摘出で放射線治療と組み合わせたほうが得策な症例もあ $3^{2(3) 5) 13) 15)}$.

この部の腫瘍としてみられるのは，髄膜腫，三叉神経 鞘腫, 類上皮腫や脊索腫などである。これらの手術では, 骨構造だけでなく, アプローチの障害物としての vein of Labbé や temporal bridging vein と深部の静脈, 特に錐体 静脈（superior petrosal vein；SPV）やテント切痕部への

佐賀大学医学部脳神経外科 $/ \bar{\top} 849-8501$ 佐賀市鍋島 5-1-1〔連絡先：松島俊夫〕

Address reprint requests to: Toshio Matsushima, M. D., Department of Neurosurgery, Faculty of Medicine, Saga University, 5-1-1 Nabeshima, Saga-shi, Saga 849-8501, Japan 

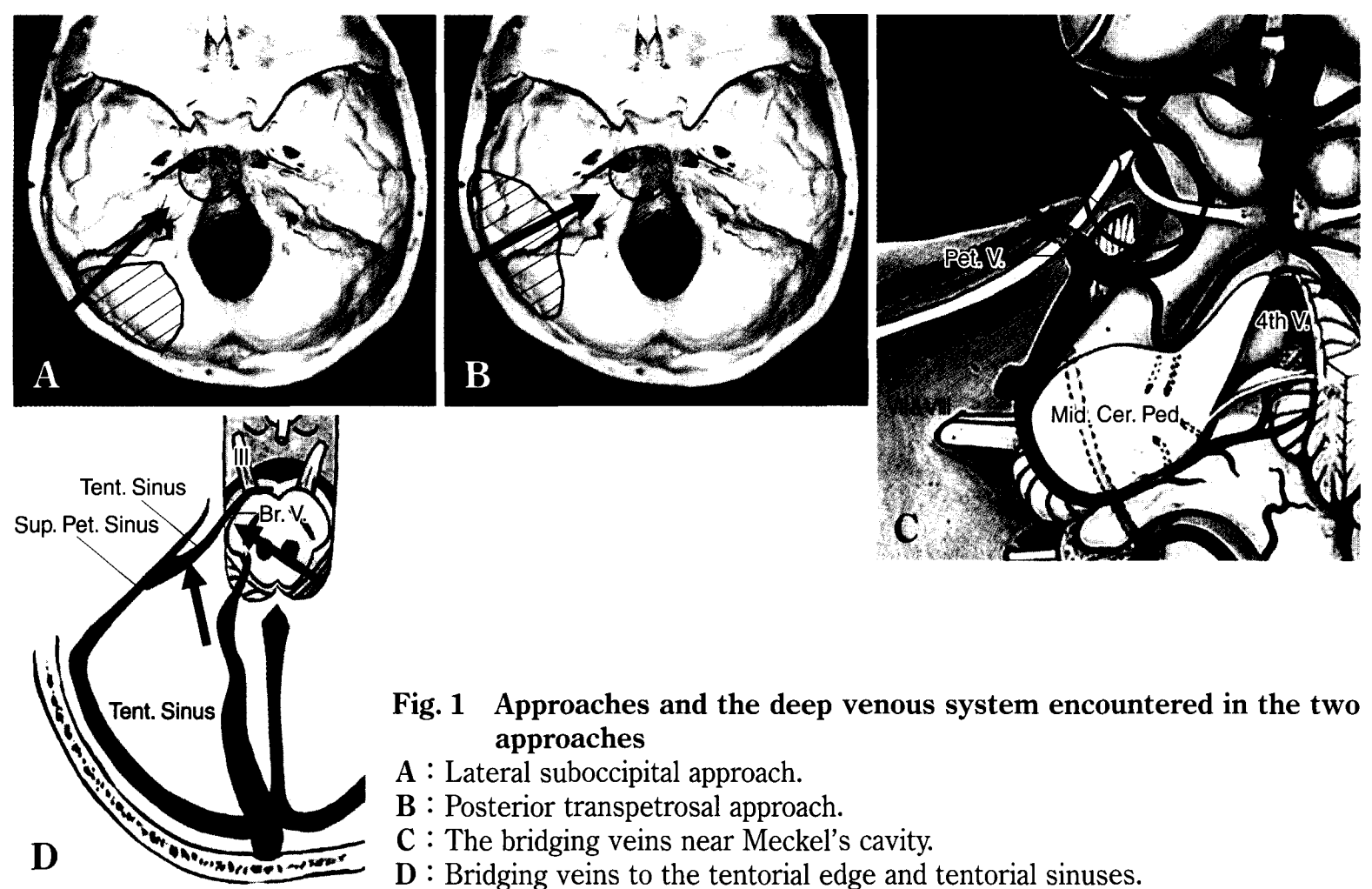

Fig. 1 Approaches and the deep venous system encountered in the two approaches

A : Lateral suboccipital approach.

B : Posterior transpetrosal approach.

C : The bridging veins near Meckel's cavity.

D : Bridging veins to the tentorial edge and tentorial sinuses.

架橋静脈やそれに続く小脳テント静脈洞が障害物とな る6)14)16) 18)25)28)，そして，それら静脈系の損傷による合 併症例も，少数例ではあるが報告されている(4)9)14)27)37). それゆえ，アプローチとともにそれら静脈の外科解剖を 十分に理解して手術を行う必要がある。

Petroclival region へのアプローチとその時遭遇する静 脈に注目し, petroclival region tumor の手術について解説 する. Petroclival region と一言で表しても，高さにかな りの幅があり，また腫瘍の伸展方向で手術法に違いがで るので，本文での到達目標部位として Meckel 腔内側部 を想定して述べていく.

\section{Petroclival region ヘのアプローチ}

Meckel 腔内側の petroclival region へのアプローチに はさまざまなものがあるが，大きくはテントの下からと 上からとそれら両者の混合型の 3 つに分かれる2)315)29). テント下からは外側後頭下開頭法 (lateral suboccipital

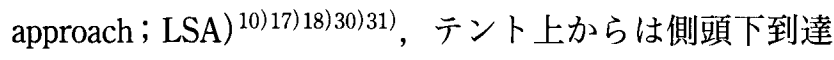
法（subtemporal approach）や前方経錐体法（anterior

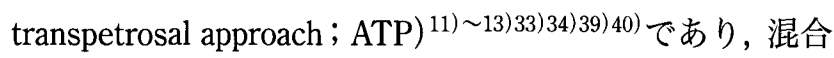
型として後方経錐体法 (posterior transpetrosal approach;

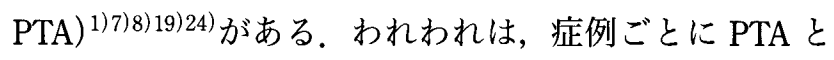
LSA を使い分けてきたが，慣れるにつれ術中解剖が理解
しやすく到達時間も少なくて済む LSA をより頻繁に用 いるようになってきた（Fig. 1A，B）．LSA は，腫煌の主 座が後頭蓋窩にある症例や, 脳幹圧迫を軽減するのみで 全摘出を目指さない症例に用いる. LSA で遭遇し問題と なるのは, SPVである (Fig. 1C) (6)14)16) 18)36). 他方, 錐 体骨を削除することにより小脳半球自身を牽引せずにす むPTA で遭遇する静脈系には, vein of Labbé, 側頭葉下 面の架橋静脈と SPV に加えてテント切痕部への架橋静 脈とその延長のテント静脈洞がある(Fig. 1D) ${ }^{16) 19) 22(25) 26) 28)}$ ，それらの静脈損傷による合併症を回 避できるよう，その微小外科解剖とそれぞれのアプロー チで術中どのように見えるかと処理法について解説する。

\section{外側後頭下開頭法 (lateral suboccipital approach : LSA)}

LSA にもバリエーションがあり, Meckel 腔内側へ向か う LSA は, 三叉神経痛に対する神経血管減圧術に用い る infratentorial lateral supracerebellar approach ${ }^{10) 17) 18220)}$ とほぼ同じである．ただし，大きな腫瘍の時は骨空を大 きくする (Fig. 2A)。このアプローチのよさは, 開頭が 単純で腫瘍に早く到達できることである。また, superior petrosal sinus を中央上方に見ながら 2 つの小脳半球面 の tentorial surface と petorsal surface を使いつつ手術を 

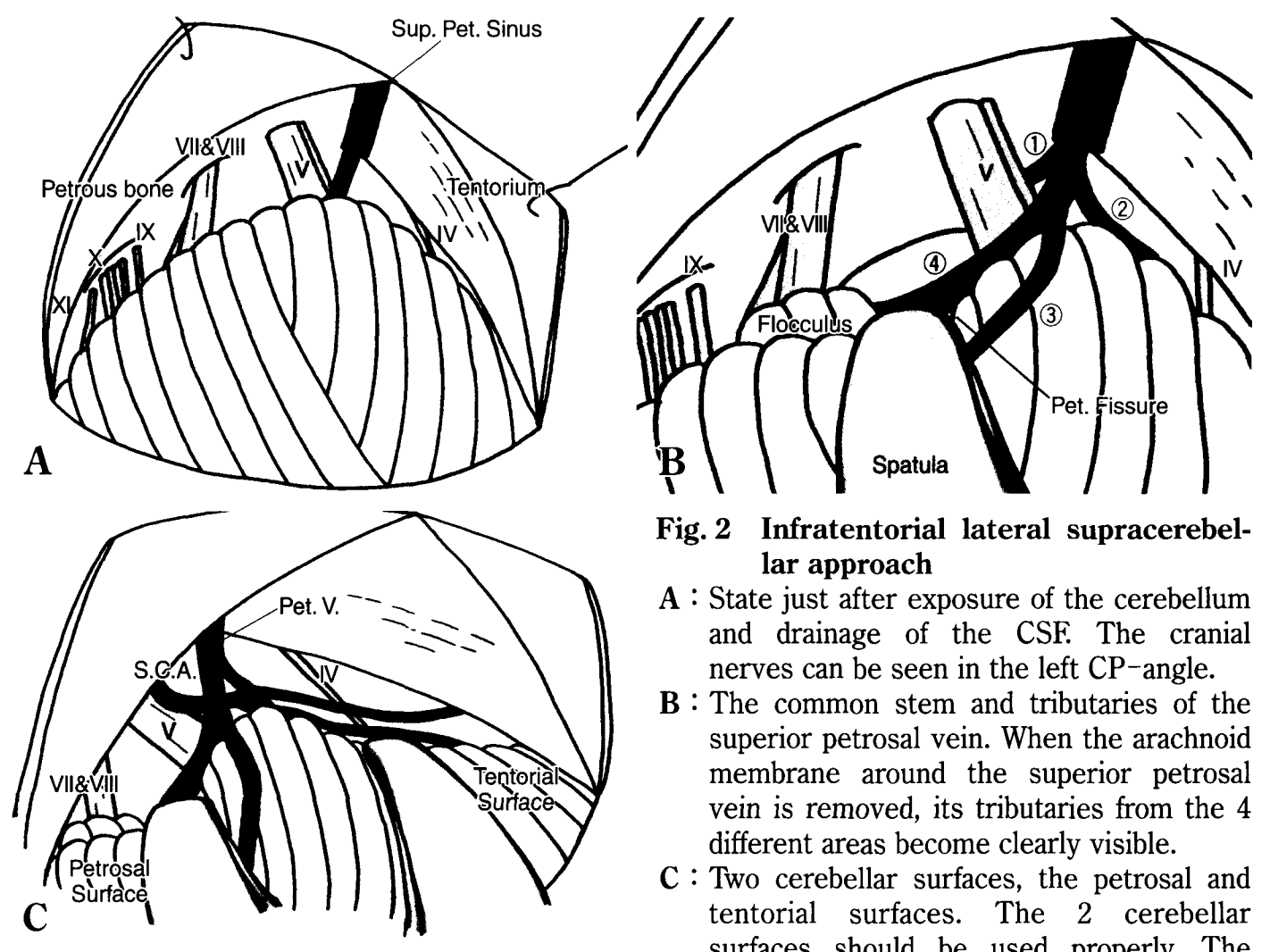

Fig. 2 Infratentorial lateral supracerebellar approach

A : State just after exposure of the cerebellum and drainage of the CSF. The cranial nerves can be seen in the left $\mathrm{CP}$-angle.

B : The common stem and tributaries of the superior petrosal vein. When the arachnoid membrane around the superior petrosal vein is removed, its tributaries from the 4 different areas become clearly visible.

$\mathrm{C}$ : Two cerebellar surfaces, the petrosal and tentorial surfaces. The 2 cerebellar surfaces should be used properly. The tentorial surface is more often used in the infratentorial lateral supracerebellar approach.

行うので, 術野の解剖学的位置関係, 腫瘍と脳神経の位 置関係などが理解しやすい（Fig. 2B，C）。ただし架橋静 脈である SPV が障害物となるので, 髄液を排液し小脳半 球を牽引しやすくした後, まず SPV 周囲のクモ膜を十分 に剝離切開し，さらに小脳半球を牽引しても架橋静脈を 損傷しなくてすむように処置しておく必要がある（Fig. 2B) ${ }^{6) 16) 36)}$.

LAS の手術適応例は, (1)たとえ中頭蓋窩に腫瘍が存在 したとしても小さく，主体が後頭蓋窩に存在する腫瘍， (2)全身状態などの条件から全摘出を目指さず，後頭蓋窩 の脳幹圧迫の減圧を目指す症例などである.

\section{Infratentorial lateral supracerebellar approach の基本的手技}

LSA ではまず髄液排除が重要である.手術前に留置し た腰椎ドレナージから排液するか, 硬膜切開後, 大孔部 で十分に髄液を排除する。

硬膜を開いて小脳半球を牽引しはじめたら，まず SPV 周囲のクモ膜を剝離すべきである，多くの場合，SPV は 内耳孔と Meckel 腔の間の上錐体静脈洞へ 2 3 本の架 橋静脈を作っているので, 内耳孔近傍の小脳片葉の上部 からクモ膜を切離し, SPV を遊離可能にする (Fig. 2B，3

A，B）。そして，2つの小脳半球面, tentorial surface と petorsal surface やSPV, 聴神経および内耳孔などの関係 を確認し，オリエンテーションをつけてから目的の病変 へ向かう (Fig. 2C, 3B). 周囲クモ膜を㕷離しても SPV の分枝が障害物となり, 切断しなければ十分な術野を確 保できないこともあるが，できるかぎり温存するように 努力する (Fig. 2B).

Meckel 腔内側部の petroclival region へ向かうには, 内 耳孔から離れた小脳半球面, tentorial surface を用いたほ うが得策である。この場合 SPVより正中側で tentorial surface を通過する. 小脳上面を牽引すると比較的早く腫 瘍後縁が見えはじめる（Fig. 3A，B）。髄膜腫の場合，ま ずは腫場からの出血量を減らすために, 小脳テント面と 錐体骨面の腫瘍付着部を凝固, 剝離する.この初期段階 では術野は広くないが, 手術用顕微鏡の視線を小脳テン ト面に平行に入れると, 操作に十分なスペースが得られ る.SPVの周囲のクモ膜を剥離すると, さらにスペース は広がる（Fig. 3B）。 その後, 腫瘍の内減压を行うといつ そう術野は広くなる。われわれは髄膜腫の場合のみ内減 圧の初期にパル®を用いている，腫瘍を縮小させ，腫瘍 が動くようにした後, 脳幹や脳神経からクモ膜を温存し ながら腫瘍の剶離を行う（Fig. 3C）。後頭蓋窩腫瘍をほ 

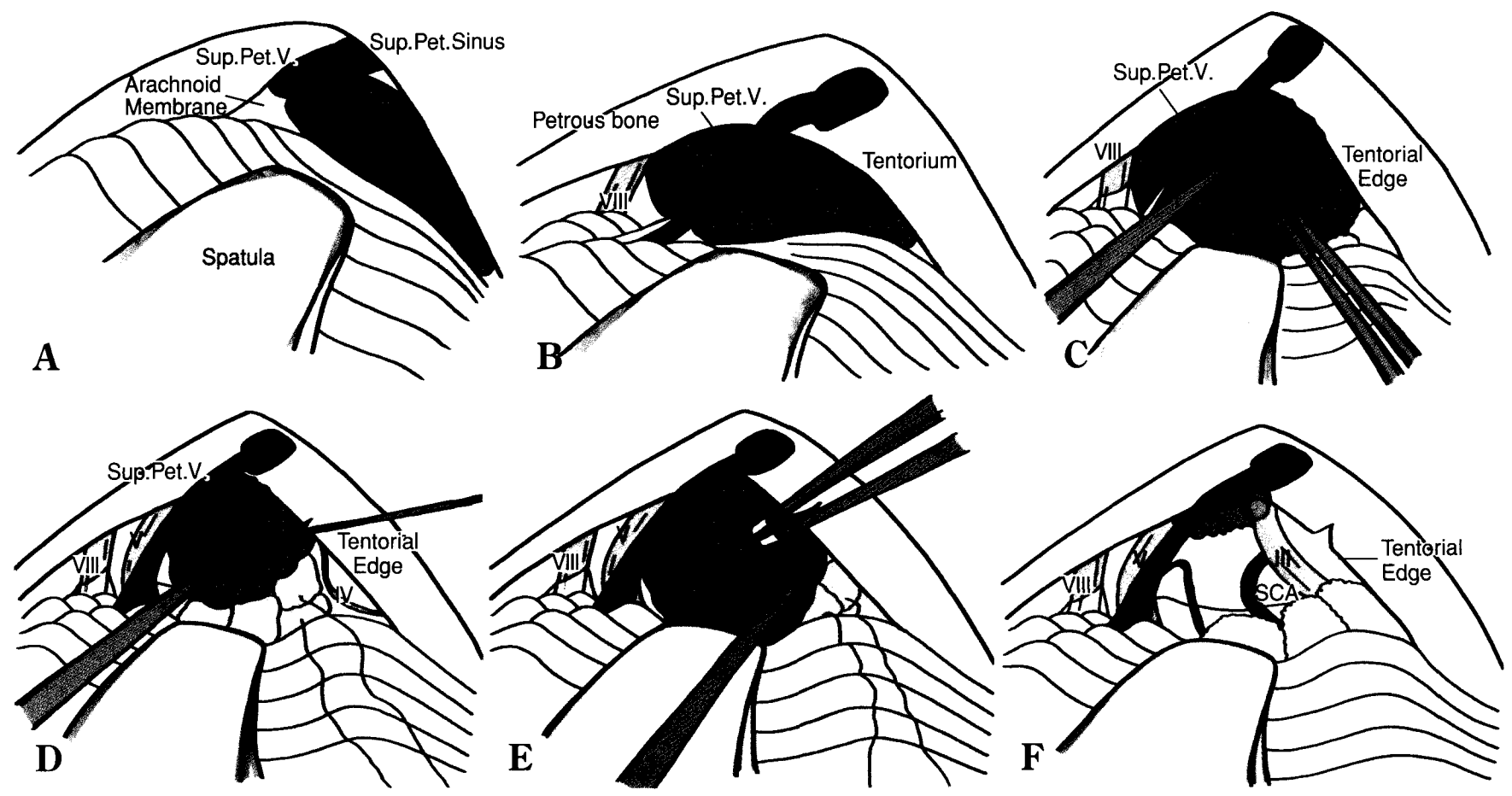

Fig. 3 Surgery for petroclival meningioma excision through the lateral supracerebellar transtentorial approach

A : State just after entering the intracranial region.

B : Dissection and removal of the arachnoid membrane around the superior petrosal vein.

C : Coagulation of the tumor attachment, internal decompression and removal of the tumor in the posterior fossa.

D : Incision of the tentorial edge from the inferior side.

E : Removal of the supratentorial tumor from the posterior fossa side.

F : State after subtotal removal of the tumor. The oculomotor nerve and the SCA are visible. A small piece of the calcified meningioma can be seen just medial to Meckel's cavity.

ぼ摘出してしまうと小脳橋角部上部に空洞ができ，テン ト切痕部がよく観察できるようになる。 その段階まで進 み, 次にテント切痕部を切開して中脳側面からテント上 の病変の処理を行う。このように transtentorial approach を下方より追加できる（Fig. 3D〜F $)^{10)}$.

われわれが infratentorial lateral supracerebellar transtentorial approach で摘出した petroclival region 髄膜腫例 を示す。

\section{【症 例】}

脳ドックで, petroclival region の無症候性髄膜腫がみ つかった（Fig. 4A，B）。この髄膜腫はテント上下にまた がつて存在し, CT スキャンで Meckel 腔内側部に骨増殖 がみられたことょり, 同部から腫瘍が発生したものと考 えられた。この腫瘍に対して infratentorial lateral supracerebellar approach に transtentorial procedure を加え, 腫 瘍を要全摘出した (Fig. $4 \mathrm{C}, \mathrm{D})$ ，後頭蓋窩腫瘍の大半を 摘出したところ, 内耳孔近傍まで圧迫され後方へ変移し た三叉神経が観察され，腫瘍が Meckel 腔内側より発生 したものと確認された。 その後テント切痕をわずかであ
るが切断し，テント上腫瘍を引きずり出しながら摘出し た. 第 4 脳神経を損傷したが, 術後複視の症状は出現し なかった。

\section{錐体静眽（SPV）}

LSA で障害物となる SPV の閉塞による合併症も，まれ ではあるが報告されている49)14)27)37). その重篤な合併症

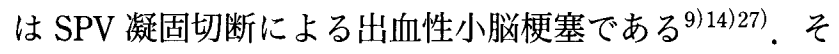
の合併症を回避するためには,できるかぎり SPV を温存 すべきである．それでも時として分枝を切断しなければ ならないこともあり，そのためにはSPV の詳細な外科解 剖を熟知しておく必要がある (Fig. 5A)。

SPV は上錐体静脈洞への draining point の観点から 3 つに分けられる。それらは, (1)内耳孔の直上にある intermediate type と, (2)それより前方正中側にある medial type, (3)それより後方外側にある lateral type である16)17)21). Medial type が多く, 通常内耳孔の上部から Meckel 腔に かけて 1 3 本存在する。 
Fig. 4 Pre- and post-operative MRI of the petroclival meningioma

A : Preoperative MRI, enhanced T1-WI, axial view. The meningioma located near Meckel's cavity compresses the pons.

B : Preoperative MRI, enhanced T1-WI, sagittal view. The tumor is located at the supra-and infra-tentorial areas.

C : Postoperative MRI, enhanced T1-WI, axial view. The tumor was almost removed, but the dura mater near Meckel's cavity was enhanced. A residual tumor is suspected.

D : Postoperative MRI, enhanced T1-WI, sagittal view.
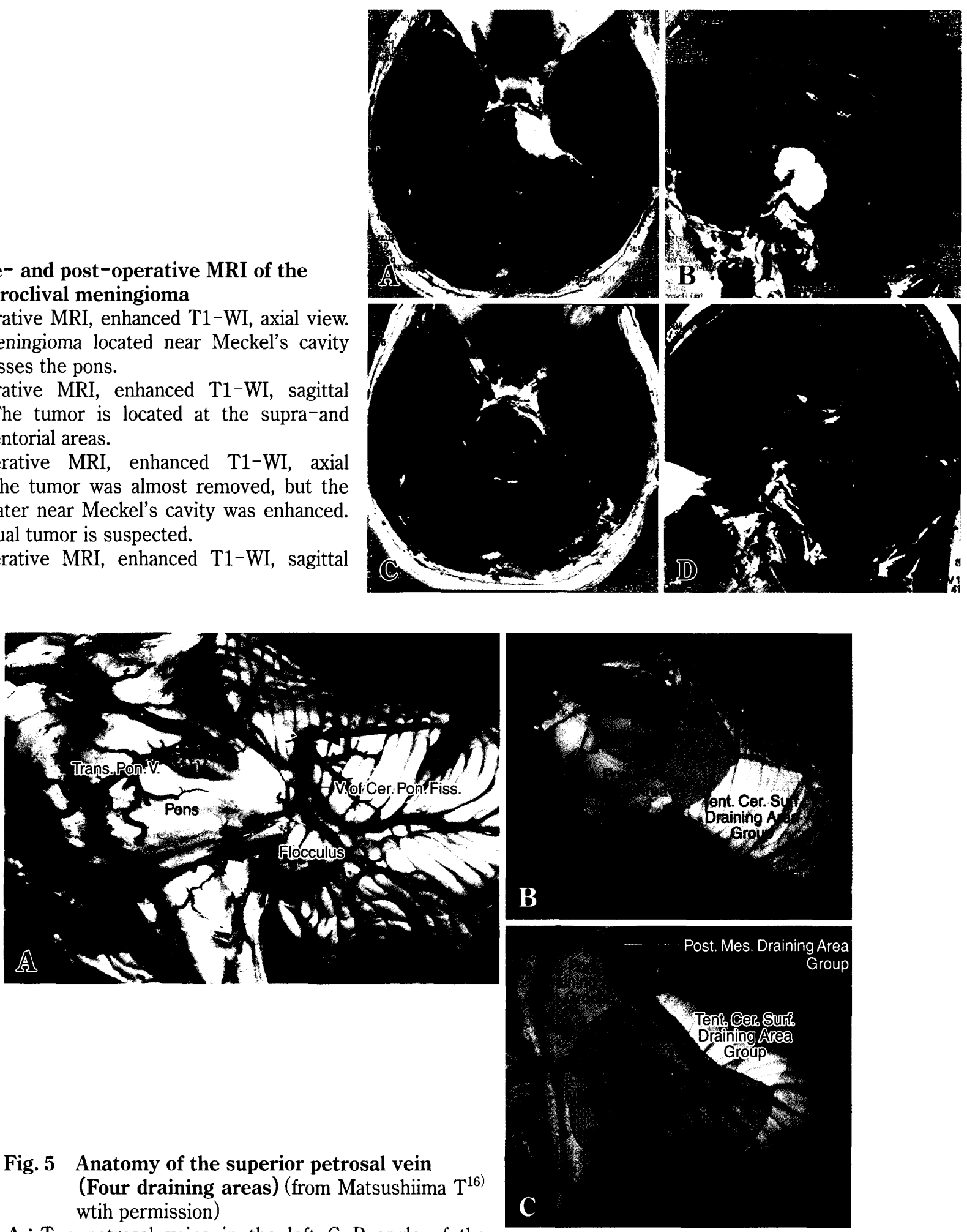

Fig. 5 Anatomy of the superior petrosal vein

(Four draining areas) (from Matsushiima $\mathrm{T}^{16)}$ wtih permission)

A : Two petrosal veins in the left $\mathrm{C}-\mathrm{P}$ angle of the autopsy specimen, oblique view from the left side.

B : Four draining areas of the petrosal vein, left superolateral view.

C : Four draining areas of the petrosal vein, left lateral oblique view.

D : Four draining areas of the petrosal vein, posterior view.

Blue: Anterior pontomesencephalic draining area group, Green: Posterior mesencephalic draining area group, Yellow: Tentorial cerebellar surface draining area group,

Pink: Petrosal fissure draining area group.

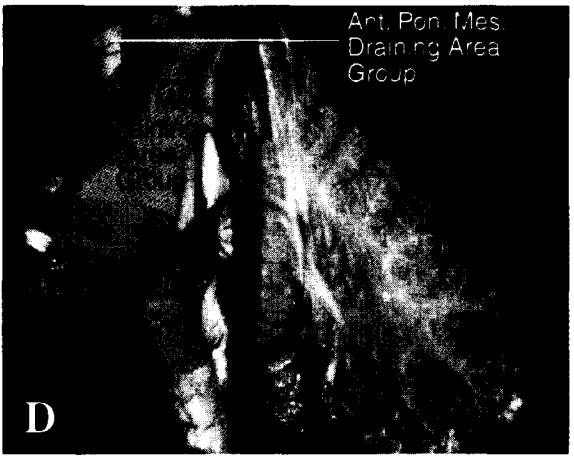




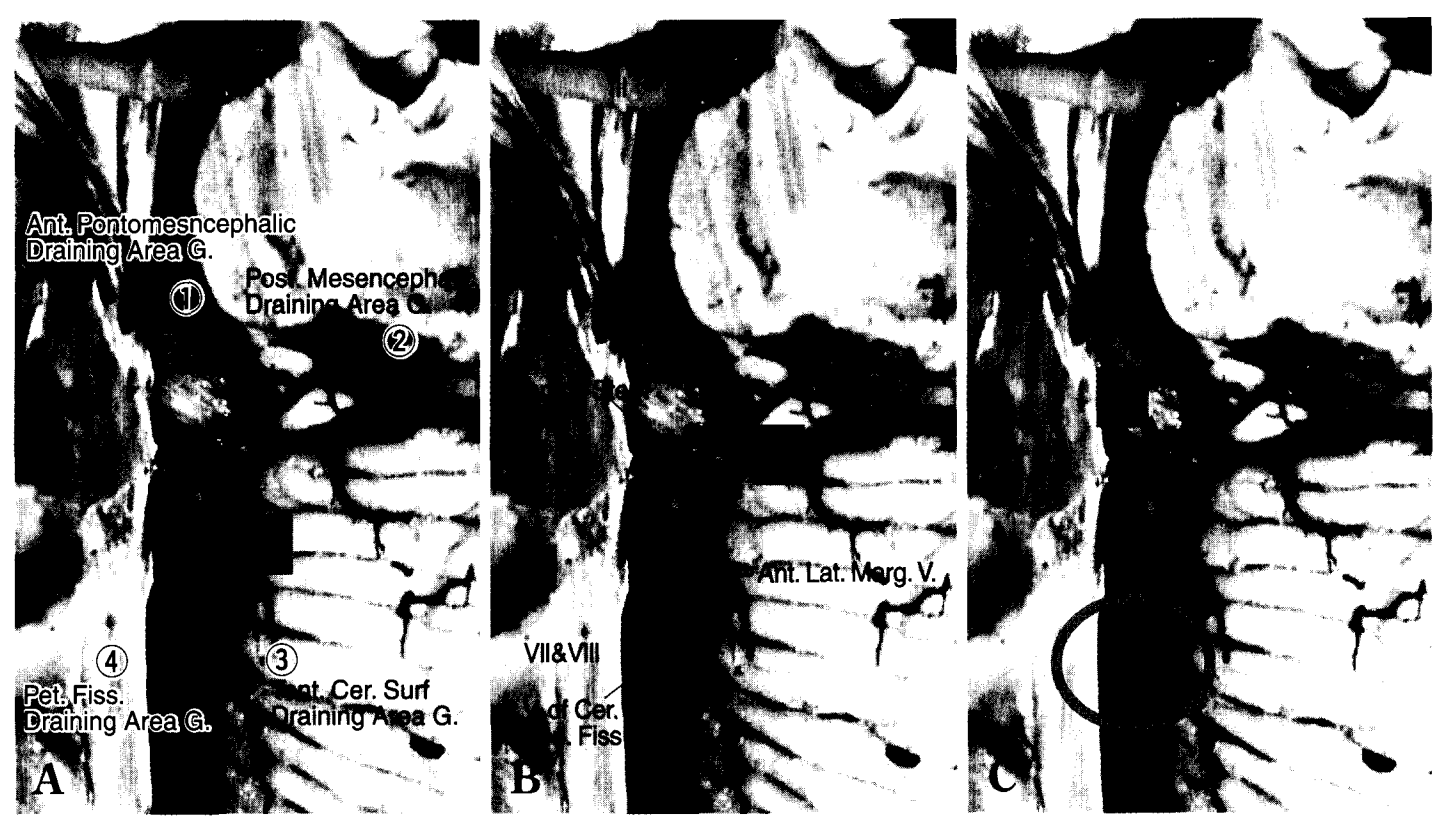

Fig. 6 Cutting order of the superior petrosal vein (Steps from 1 to 3 are indicated in the figures) (from Matsushiima $\mathrm{T}^{16)}$ wtih permission)

A : The common stems of the petrosal vein receiving its tributaries from the 4 draining areas. Two common stems of the petrosal vein can be seen in the left $\mathrm{C}-\mathrm{P}$ angle. The vein which can be cut most safely is the tributary coming from the tentorial cerebellar surface 1 .

(1): Anterior pontomesencephalic draining area group, (2): Posterior mesencephalic draining area group, (3): Tentorial cerebellar surface draining area group, (4): Petrosal fissure draining area group.

B : The tributary which can be cut next is the one coming from the posterior mesencephalic area 2 .

C : The tributary which may be cut next is the one coming from the anterior pontomesencephalic area 3 .
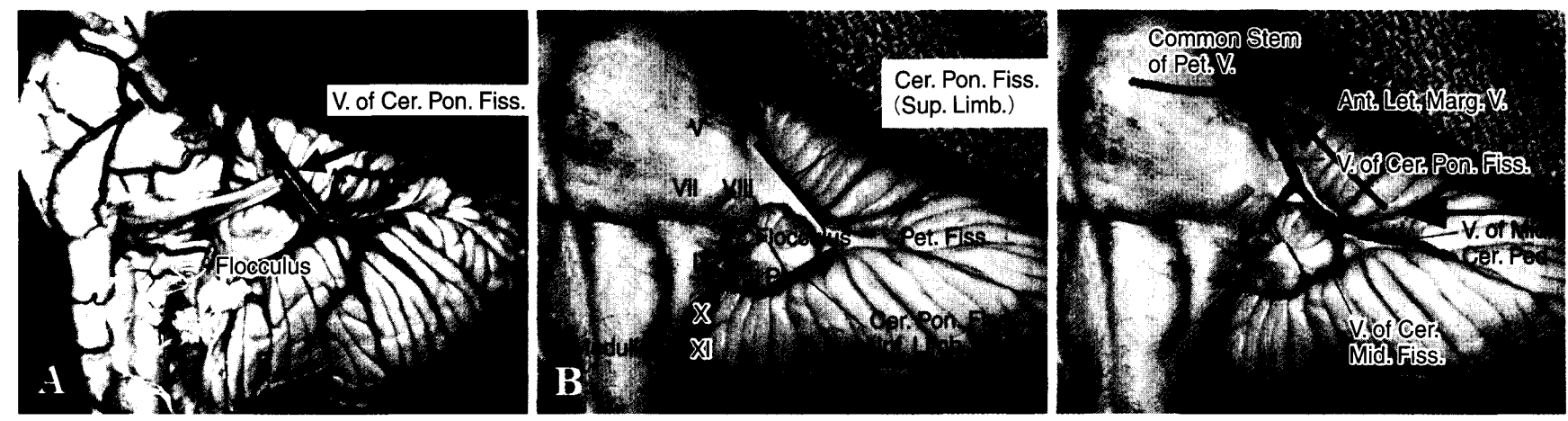

Fig. 7 Surgical anatomy of the vein of cerebellopontine fissure

A : The vein of cerebellopontine fissure in the left $\mathrm{C}-\mathrm{P}$ angle.

B : Anatomy of the cerebellopontine fissure. The cerebellopontine fissure is formed by the pons and the petrosal cerebellar surface. It has superior and inferior limbs.

$\mathrm{C}$ : The relationship between the superior limb of the cerebellopontine fissure and the vein of cerebellopontine fissure. In order to remove the arachnoid membrane around the vein of cerebellopontine fissure, the superior limb of the cerebellopontine fissure should be followed from flocculus to Meckel's cavity.

他方, SPV は還流領域から 4 つのグループに分けるこ とができる $(\text { Fig. 5B〜D })^{16)}$. (1)上部脳幹表面から血流を 集める anterior pontomesencephalic draining area group, (2)中脳背側部の cerebellomesencephalic fissure 領域から 血流を集める posterior mesencephalic draining area group,
(3)小脳 tentorial surface から血流を集める tentorial cerebellar surface draining area group, (4)第四脳室や延髄から 血流を受け, cerebellopontine fissure を上行する petrosal fissure draining area group の 4 つである.これらからの分 枝を集め，徐々に太くなり，common stem となる，それ 
Fig. 8 Pre- and postoperative MRIs in a case of dumb-bell shaped trigeminal neurinoma

A : Preoperative MRI, enhanced T1-WI, axial view. The dumb-bell shaped neurinoma can be seen in the left middle and posterior fossa.

B : Preoperative MRI, enhanced T1-WI, sagittal view.

C : Postoperative MRI, enhanced T1-WI, axial view. The tumor was removed.

D : Postoperative MRI, enhanced T1-WI, sagittal view.

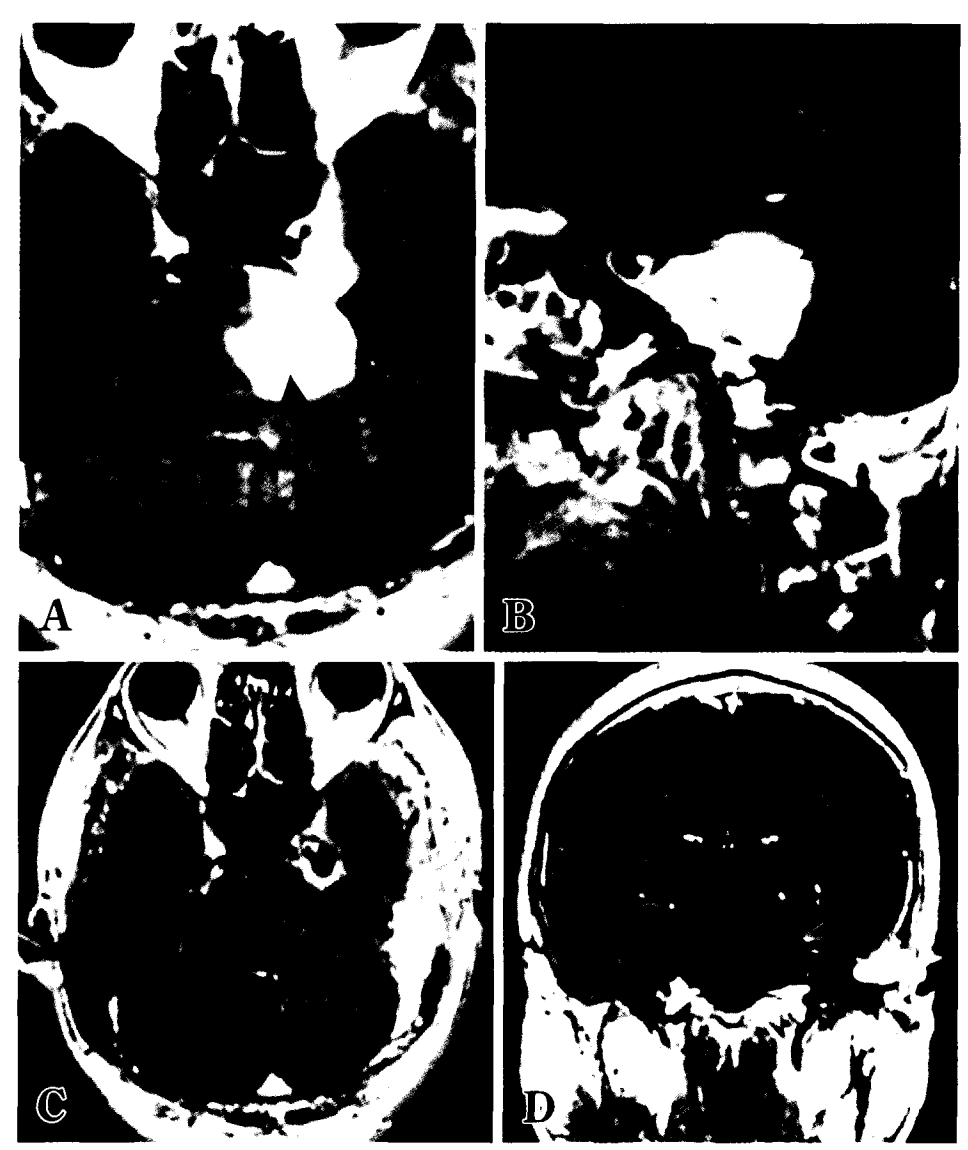

ゆえ, SPV はしばしば逆 Y 字型をしている。これら 4つ のグループのうち最も大きいものは, petrosal fissure draining area group である.SPV はしばしば複数の分枝か らなっているので，SPV を切断せざるをえない場合も， ぞの分枝から切断したらより安全か，その順番を考える 必要がある. Fig. 6A で 4 つの領域からくる分枝を, Fig. 6A〜Cでそれらを切断する際の順番を示した。しかし, 最 大の領域を還流する vein of the cerebellopontine fissure は切断すべきではないと考える16).

Petrosal fissure draining area group $の$ 最 終的 common stem が vein of the cerebellopontine fissure である（Fig. 7A). Cerebellopontine fissure は小脳半球 petrosal surface と中小脳脚が作る溝で, petrosal fissure より上部の superior limb と下部の inferior limb からなる (Fig. 7B). Vein of the cerebellopontine fissure は, 小脳片葉の上から cerebellopontine fissure の superior limb を上向する静脈であ る（Fig. 7A）。このことを熟知しておくと，内耳孔近傍， 小脳片葉上部で petrosal fissure を確認した後, 内耳孔上 部より前方部でSPV 周囲のクモ膜剝離を安全に行うこ とができる. Fig. 7C に SPV 周囲クモ膜の剝離する順路 を示す。

\section{後方経錐体法 (Posterior transpetrosal Approach ; PTA)}

PTA は錐体骨削除を行うことにより，小脳半球を率引 せずに小脳テント上下より進入するアプローチであ $3^{11788) 1922438)}$ （側頭骨を扱うので解剖が難しいような印 象があるが，アプローチに必要な外科解剖は比較的理解 しやすい ${ }^{19)}$ 。このアプローチは側頭葉牽引をそれほどし なくともよいのとATP より広い術野が得られるので, わ れわれは好んで用いている。他方, 腫瘍露出までに時間 がかかるという欠点はある。手術適応は, 腫瘍がテント 上下にまたがる症例で中頭蓋營側も後頭蓋窩側も観察 し, 手術操作しなければならない症例である. Meckel 腔 を中心にテント切痕近傍に存在するテント上下にまたが る腫瘍である1)7)15) 19)24).

\section{PTA の基本手術手技}

頭痛でみつかったテント上下にわたるダンベル型三叉 神経鞘腫の症例（Fig. 8）を提示しながら, PTAの基本 的アプローチと深部静脈系を示す。まず開頭を横洞の上 下に行い, 続いて mastoidectomy を行う（Fig. 9A〜C). 

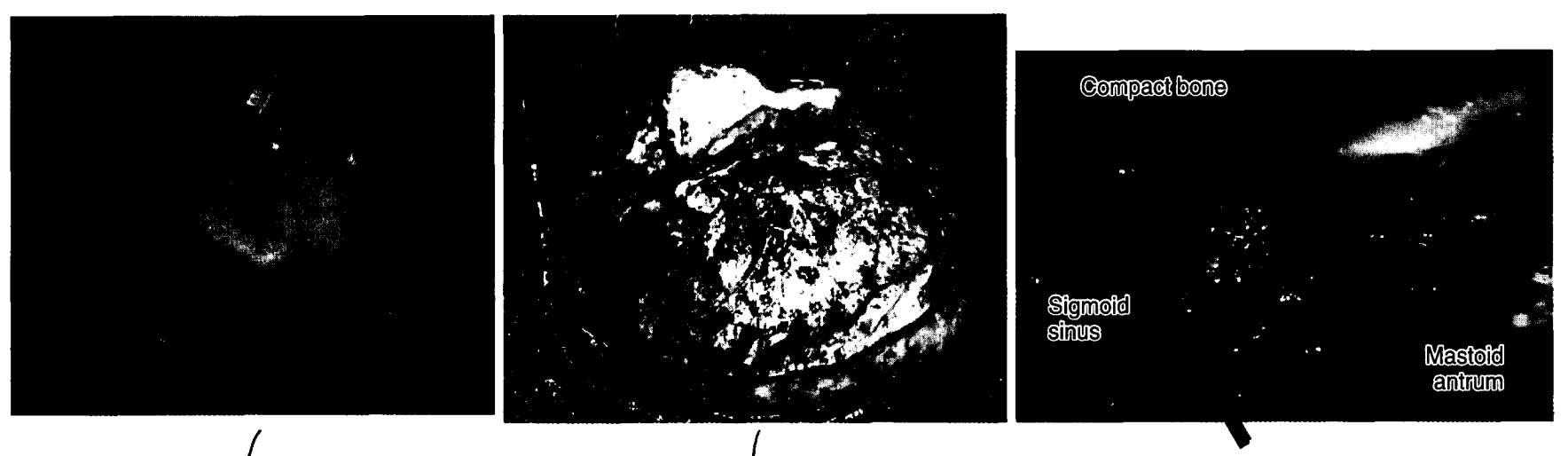

A

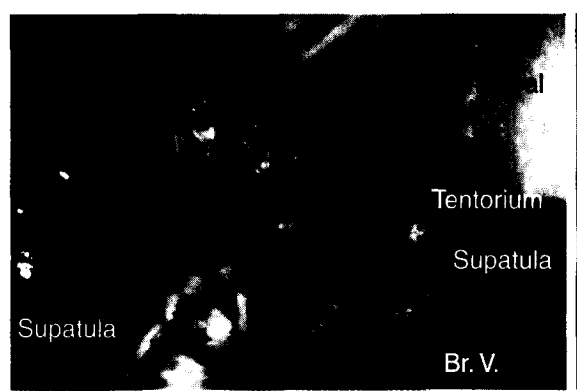

D

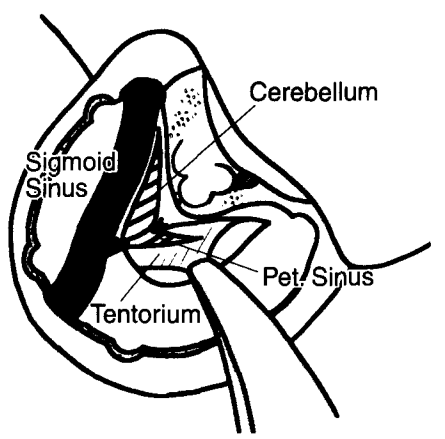

B
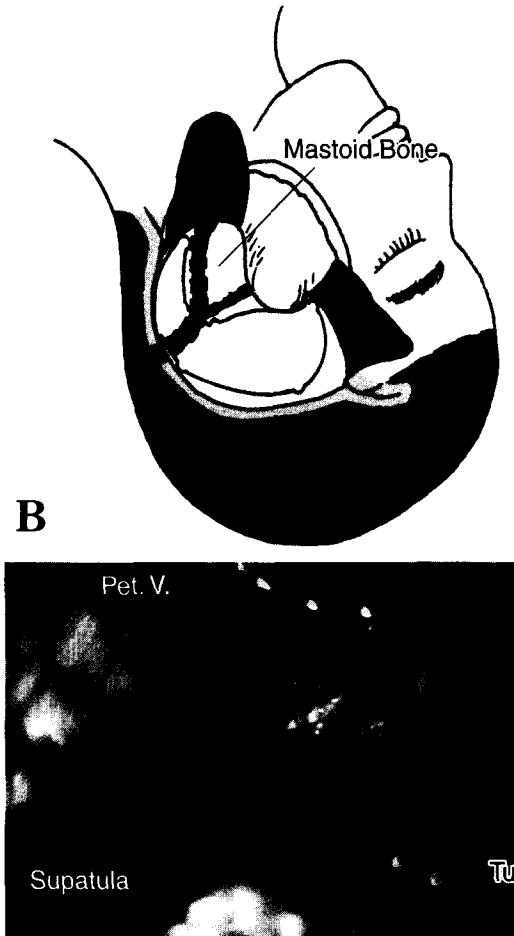

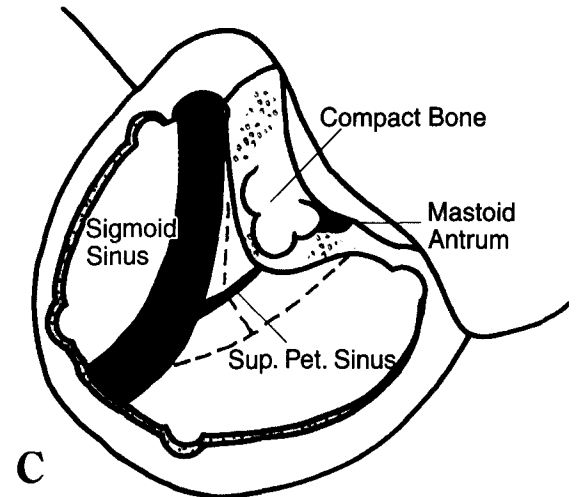

C
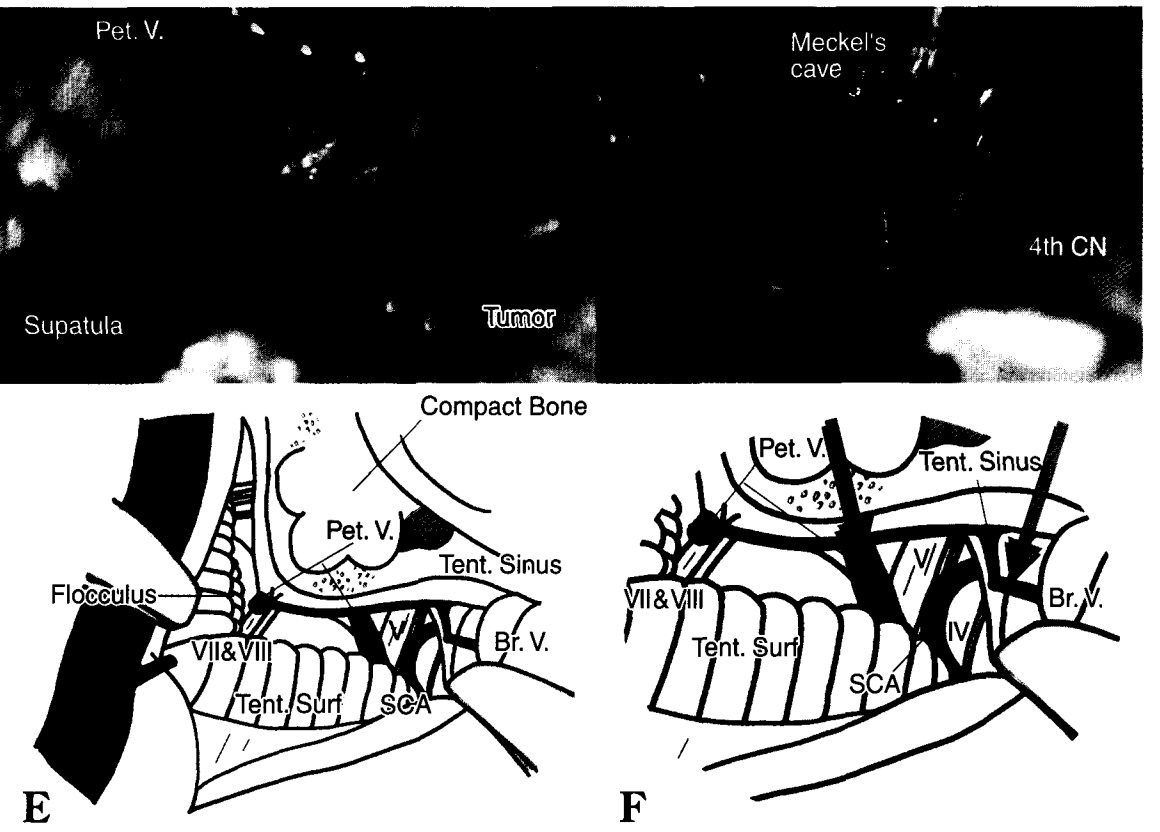

Fig. 9 Posterior transpetrosal approach

\section{A : Skin incision.}

B : Bony opening.

C : Mastoidectomy. After mastoidectomy, the presigmoid dura mater is exposed. The compact bone and the mastoid antrum can be seen.

D : Opening of the dura mater and cutting of the superior petrosal sinus. After opening of the supra- and infra-tentorial dura mater, the superior petrosal vein will be cut. A bridging vein from the inferior surface of the temporal lobe can be seen.

E : Bridging veins encountered after entering the intradural space. After incising the tentorium, bridging veins will be encountered above the acoustic meatus and near Meckel's cavity. The intraoperative photo shows the petrosal vein just posterior to the tumor. Sometimes a bridging vein to the tentorial edge and a tentorial sinus will be encountered.

F : Surgical anatomy around the tentorial edge. The intraoperative photo shows the state after removal of the tumor. The 4th cranial nerve can be seen. The illustration shows a bridging vein to the tentorial edge and the tentorial sinus. 


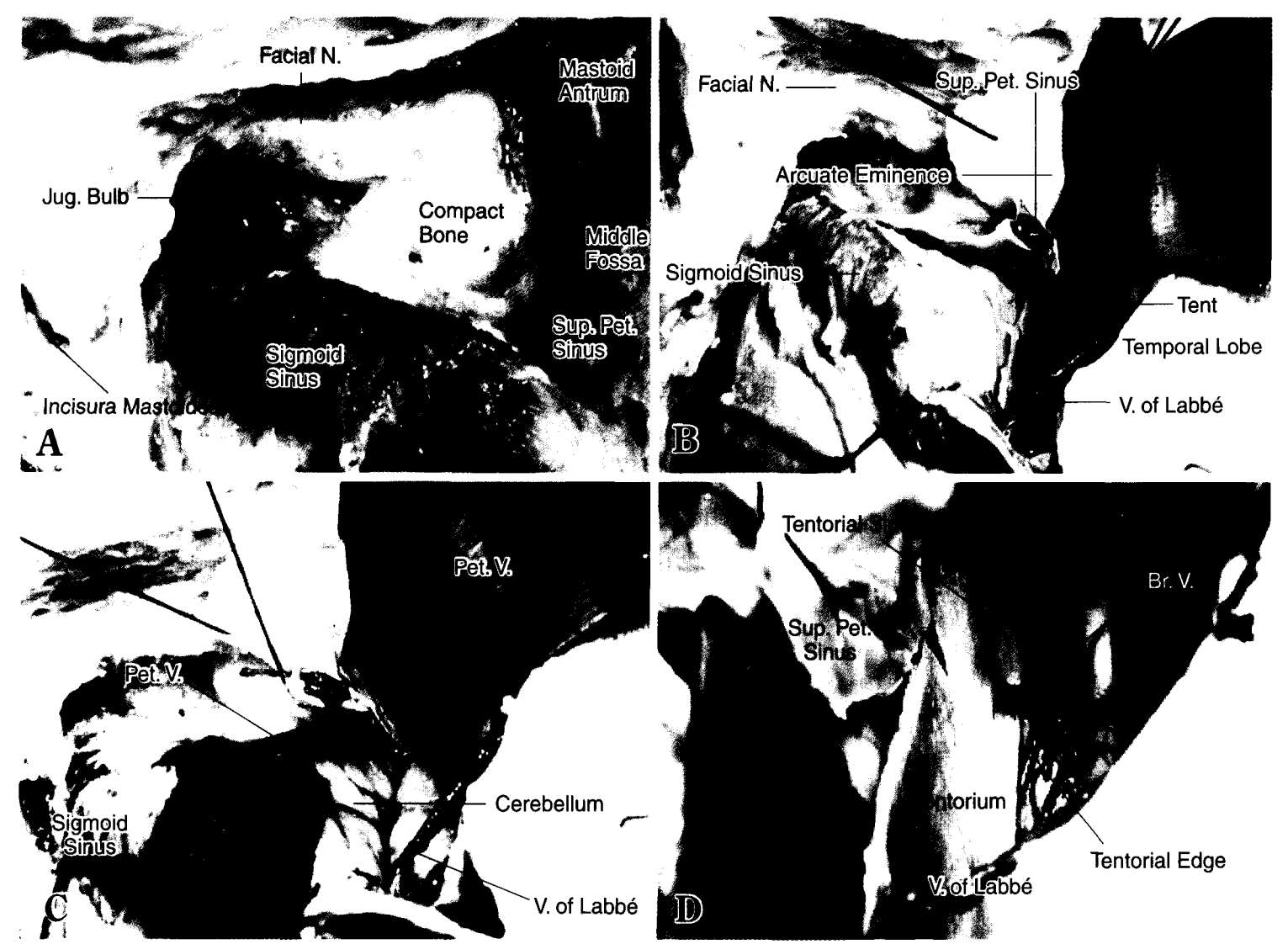

Fig. 10 Bridging veins and tentorial sinuses encountered in the posterior transpetrosal approach shown in the autopsy specimen

A : State just after mastoidectomy. After confirming the course of the facial nerve, the presigmoid dura mater is exposed.

B : Incision of the dura mater and cutting of the superior petorsal sinus. When the temporal lobe is lifted, the vein of Labbé is an obstacle.

$\mathrm{C}:$ Bridging veins in the $\mathrm{C}-\mathrm{P}$ angle encountered after incision of the tentorium. While the tentorium is being incised, a few bridging veins will be encountered from the acoustic meatus to Meckel's cavity.

D : Venous system near the tentorial edge. A bridging vein to the tentorial edge can be seen and the vein forms the tentorial sinus draining into the superior petrosal sinus.

Mastoidectomy の要領は，最初に乳突洞をみつけ，その ことにより三半規管を覆う compact bone と中頭蓋窩か ら外耳道の周りを走る顔面神経の走行を確認し, それら を損傷せずに presigmoid area の硬膜を露出することで ある(Fig. 9C)。ナビゲーションを用いると最小限の mastoidectomy が行いやすい. 続いてテント上下の硬膜を切 開した後，上錐体静脈洞を結禁する（Fig.9D）。そこで 側頭葉を持ち上げ小脳テントをみるが, この時 vein of Labbé や側頭葉下面からの架橋静脈に注意する. その後, 小脳テントを後部から切痕部へ向けて切断していくが, その途中, 内耳孔の上部近傍で上錐体静脈洞へ流入する vein of the cerebellopontine fissure に遭遇したり,テント 切痕部近傍では三叉神経近傍の架橋静脈や中脳側からテ ント切痕部への架橋静脈やそれに続く小脳テント静脈洞 に遭遇する（Fig. 9E，F）。この頃には，すでに三叉神経
鞘腫の後頭蓋營部分が見えはじめる. 小脳テントを切開 していく時, 架橋静脈や小脳テント静脈洞に遭遇するこ とがあるので, 滑車神経のみならずこれらの静脈系にも 注意し, 損傷し出血させないようにする必要がある。いつ たん出血させると, 深部のうえに出血量が多く, 止血す るのが容易でない. 小脳テントを完全に切開し, 最終的 に後頭蓋窩から中頭蓋窩にわたりテント上下に存在した 腫瘍を摘出する (Fig. 8C, D).

\section{テント切痕部静眽系}

テント切痕部近傍の静脈には, 切痕への架橋静脈と切 痕部に沿って Meckel 腔へ向かう小脳テント静脈洞があ る (Fig. 10, 11 A $)^{16) 21) 22) 26)}$.

この部のテント切痕への架橋静脈は, 中脳外側部から 

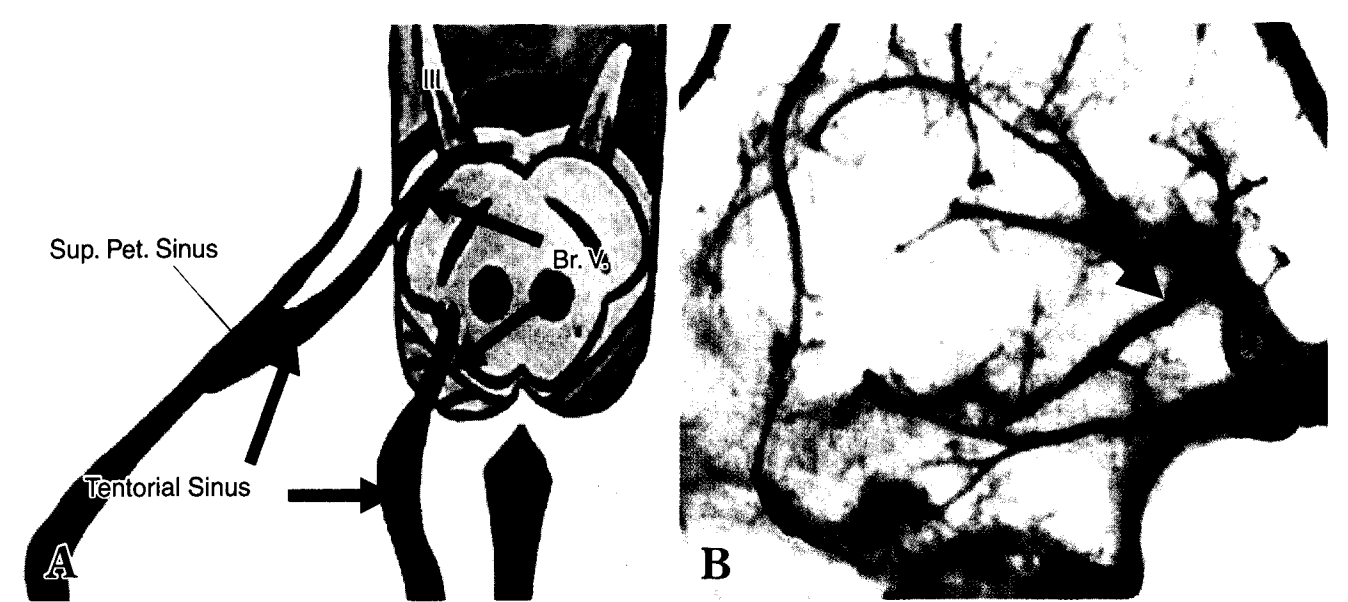

Fig. 11 The venous system near the tentorial edge and angiography

A : Illustration demonstrating bridging veins and tentorial sinuses near the tentorial edge.

B : Venous phase of the angiography, lateral view. The tentorial sinus is indicated by an arrow.

テント切痕部への架橋静脈である. 時として小児期に成 長過程で存在する大きな静脈が架橋静脈として遺存して いることもある21222)。これらの架橋静脈はそれに続いて 小脳テント内に静脈洞を作り，それらが上錐体静脈洞や 直洞へ流入する。それゆえ，小脳テントを切断して小脳 テント切痕部へ近づいたら，静脈洞を警戒しながら少し ずつ切断したほうがよい.

\section{考 察}

Petroclival region tumor の手術では, どのアプローチを 選ぶかがまず問題となる。一つのアプローチでこの部の すべての腫瘍摘出ができるわけでなく，すでに述べた 3 つのアプローチから症例ごとに選ぶこととな

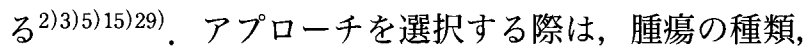
大きさ, 存在部位 (テント上下), 海綿静脈洞浸潤の有 無，通過する部位の静脈系，腫場のどの部をどこまで摘 出するかという観点とともに，選ぶアプローチへの術者 の慣れなどを基準とする.ガンマナイフ治療がある現在, mortality のみならず morbidity も重要で, 必ずしも腫瘍 を全摘出せずともよい成績が得られている13).

LSA といっても, petroclival region tumorに対する LSA は, infratentorial lateral supracerebellar apporach で ある(10)17)18)。このアプローチで行い，小脳テントを下方 より切開すると，テント上に伸展した腫瘍が極端に大き くなければ，後頭蓋窩に主座を置く petroclival meningiomaでは十分に摘出できる ${ }^{10)}$. Samii $ら^{30)}$ は，最近 行った 70 例中 24 例はこの単純なアプローチで腫瘍適 出ができたと報告している，また，症例によっては，内 耳孔の前方にある suprameatal bony bulging を削除する
とより徹底的に腫瘍摘出できるとして, retrosigmoid intradural suprameatal approach と呼び報告している3132). ソノペットを用いると，内耳孔の前方にある suprameatal bony bulging 削除はそれほど危ない手技ではないと思わ れる.

われわれも petroclival meningiomaに対して以前はPTA を主に用いた。しかし経験を積むにしたがい，Samii $5^{3031)}$, 川又ら ${ }^{10)}$ 同様, 後頭蓋筒側からのみの infratentorial lateral supracerebellar approach で transtentorial approch を追加すると，かなり大きな腫瘍摘出もできる と思うようになってきた。 ただし，腫瘍の主座が中頭蓋 窩に大きく存在したり, 海綿静脈洞へ浸潤しているよう な腫瘍では無理である，それゆえ，症例ごとに腫瘍の存 在部位や栄養血管のくる方向を考慮し，アプローチを選 択する必要がある。

SPV に関して，多数例の三叉神経痛に対する減圧術を 報告した McLaughlin ら ${ }^{23)}$ は切断してもほとんぞ問題な かったと述べており, 腫瘍例に関しても川又ら ${ }^{10)}$ は腫瘍 によって圧排されすでに閉塞していることも多く，大多 数の症例で問題ないとしている。しかし，少数例ではあ るがSPV を切断したための出血性脳梗塞などの重篤な 合併症例が報告され，死亡例すらある4)9144)27)37). Koerbel らの錐体先端部髄膜腫手術例 57 例における最近の調 査 ${ }^{14)}$ では, SPV を温存した群 (27 例) では合併症がみら れなかったのに対し, 切断した群 (30 例) では小脳浮腫 などの合併症が生じている，合併症の発生に切断した SPV の太さに関連しており, SPV を温存することの重要 性が強調されている。われわれも petroclival meningioma の手術でやむなくSPV を切断したところ脳幹出血をき たした 1 症例を経験した。手術時間が長い症例や小さい 
腫瘍で手術時間が短くてもSPV がまだ開存している症 例ではできるだけ温存して腫瘍摘出を行うべきであろ う。そのためには Sugita $~^{35)}$, Fujimaki $ら^{6)}$ や田草川 ${ }^{36)}$ が提唱しているように，架橋静脈周囲のクモ膜を十分に 剝離し，架橋静脈が伸展できるように処理をするべきで ある.しかし，SPV 分枝をどうしても切断せざるをえな い場合は, 細く安全な架橋静脈から順次切断すべきであ る ${ }^{16)}$ 。われわれは, SPV へ流入する 4 つの還流静脈グ ループのうち，小脳 tentorial surface から血流を集める tentorial cerebellar surface draining area group の分枝は細 いので切断できると考えている，次に安全なものは，中 脳背側部の cerebellomesencephalic fissure 領域から血流 を集める posterior mesencephalic draining area group の 分枝であろう．最後まで温存すべきなのが, cerebellopontine fissure を上行する petrosal fissure draining area group の太い分枝である.

PTA でアプローチする場合, petroclival region tumor が大きくとも，小脳半球を率引しないので SPV はほとん ぞ問題ないと考えられるが，むしろ側頭葉を持ち上げる vein of Labbé の損傷に注意すべきである ${ }^{19) 24) 25)}$.この他, 小脳テントにはまれではあるがテント静脈洞が存在する 症例があり,気をつける必要がある22226).われわれも1例 で小脳テント切痕部を切断したところ血圧が下がるほど の大出血を突然起こしたことがある。それ抌え，術前の 画像診断, 特に脳血管撮影静脈相で切開する小脳テント, 特に切痕部近傍部に大きなテント静脈洞が存在しないか 見ておく必要がある（Fig. 11）。

以上, petroclival region tumor に対するアプローチ， LSA と PTA の基本的手術手技とそれらにおける深部静 脈の外科解剖と術中処理について解説した.

\section{文 献}

1) Al-Mefty O, Ayoubi S, Smith RR: The petrosal approach: Indication, technique, and results. Acta Neurochir Suppl (Wien) 53: 166-170, 1991.

2) Bambakidis NC, Kakarla UK, Kim LJ, Nakaji P, Porter RW, Daspit CP, Spetzler RF : Evolution of surgical approaches in the treatment of petroclival meningiomas: A retrospective review. Neurosurgery 61 (5 Suppl 2): 202-211, 2007.

3) Bricolo AP, Turazzi S, Talacchi A, Cristofori L: Microsurgical removal of petroclival meningiomas: A report of 33 patients. Neurosurgery 31:813-828, 1992.

4) Distelmaier P: Complications of the operative neurosurgical treatment of trigeminal neuralgia. Zentralbl Neurochir $37: 119-125,1976$.

5) Erkmen K, Pravdenkova S, Al-Mefty O : Surgical management of petroclival meningiomas: Factors determining the choice of approach. Neurosurg Focus 19: 1-12, 2005.

6) Fujimaki $T$, Kirino $T:$ Combined transhorizontal-supracere- bellar approach for microvascular decompression of trigeminal neuralgia. British J Neurosurg 14:531-534, 2000.

7) Haddad GF, Al-Mefty O: Petrosal "presigmoid" approach to the clivus. in Torrens M, Al-Mefty O, Kobayashi S(eds) : Operative Skull Base Surgery. New York, Churchill Livingstone, 1997, pp.313-320.

8) Hakuba A, Nishimura $S$, Tanaka K, Kishi $H$, Nakamura $T$ : Clivus meningiomas: Six cases of total removal. Neurol Med Chir (Tokyo) 17: 63-77, 1977.

9) Inamasu J, Shiobara R, Kawase T, Kanzaki J : Haemorrhagic venous infarction following the posterior petrosal approach for acoustic neurinoma surgery: A report of two cases. Eur Arch Otorhinolaryngol 259: 162-165, 2002.

10）川又達朗, 片山容一：錐体斜台部病変に対する Lateral supracerebellar transtentorial approach. No Shinkei Geka 34: 567-575, 2006.

11) Kawase $T$, Shiobara $R$, Toya $S$ : Middle fossa transpetrosal-transtentorial approaches for petroclival meningiomas: Selective pyramid resection and radicality. Acta Neurochir (Wien) 129: 113-120, 1994.

12) Kawase T, Shiobara R, Toya $S$ : Anterior transpetrosaltranstentorial approach for sphenopetroclival meningiomas : Surgical method and results in 10 patients. Neurosurgery 28: 869-876, 1991.

13）嘉山孝正, 園田順彦, 櫻田 香, 佐藤慎哉, 斎藤伸二郎： Multimodality を用いた petroclival meningioma の治療. 脳 外誌 14: 462-468, 2005.

14) Koerbel A, Gharabaghi A, Safavi-Abbasi S, Samii A, Ebner FH, Samii M, Tatagiba M: Venous complications following petrosal vein sectioning in surgery of petrous apex meningiomas. Eur J Surg Oncol, 2008[Epud ahead of print]

15）久場博司, 松島俊夫, 松角宏一郎, 名取良弘, 稲村孝紀, 福井仁士: 後頭蓋窩類表皮腫の進展範囲と手術アプロー 千. 脳外誌 $9: 10-15,2000$.

16）松島俊夫：後頭蓋窩の微小外科解剖と手術。東京, サイ メッド・パブリケーションズ, 2006, pp.33-42.

17) Matsushima T, Fukui M, Suzuki S, Rhoton AL Jr: The microsurgical anatomy of the infratentorial lateral supracerebellar approach to the trigeminal nerve for tic douloureux. Neurosurgery 24:890-895, 1989.

18）松島俊夫, 福井仁士, 山下正憲, アルバート・ロートン： 三又神経痛に対する後頭蓋窩神経血管減压術一特に Infratentorial lateral supracerebellar approach について. No Shinkei Geka 15: 1047-1054, 1987.

19）松島俊夫, 勝田俊郎, 名取良弘, 福井仁士, アルバート • ロートン: 後方経錐体法一経乳様突起到達法一。松野治 雄編: 顕微鏡下手術のための脳神経外科解剖XI. 東京, サイメッド・パブリケーションズ, 1999, pp.187-196.

20）松島俊夫, 勝田俊郎, 名取良弘, 福井仁土: 小脳橋角部 の微小外科解剖一特に外側後頭下開頭における 4 到達法 の違いについて一. 石井鐐二編：顕微鏡下手術のための 脳神経外科解剖IX. 東京, サイメッド・パブリケーショ ンズ, 1997, pp.103-110.

21) Matsushima T, Rhoton AL Jr, Oliveira ED, Peace D : Microsurgical anatomy of the veins of the posterior fossa. J Neurosurg 59: 63-105, 1983.

22) Matsushima T, Suzuki SO, Fukui M, Rhoton AL Jr, de Oliveira $\mathrm{E}$, Ono $\mathrm{M}$ : The microsurgical anatomy of the tentorial sinuses. J Neurosurgery 71: 923-928, 1989.

23) McLaughlin MR, Jannetta PJ, Clyde BL, Subach BR, Comey CH, Resnick DK: Microvascular decompression of cranial nerves: Lessons learned after 4,400 operations. $J$ 
Neurosurg 90:1-8, 1999.

24）大西英之：Transpetrosal Approach. No Shinkei Geka 22 : 509-515, 1994.

25）大西英之, 中瀬裕之, 東保 肇，橋本研二，渡部安晴， 伊東民雄, 山田圭介, 佐藤直樹, 唐澤 淳: 頭蓋底病変 へのアプローチにおける Labbé 静脈温存法, 脳卒中の外 科 $21: 305-310,1993$.

26) Ono M, Rhoton AL Jr, Barry M : Microsurgical anatomy of the region of the tentorial incisura. J Neurosurg $60: 365^{-}$ 399, 1984.

27) Ryu H, Yamamoto S, Sugiyama K, Yokota N, Tanaka K : Neurovascular decompression for trigeminal neuralgia in elderly patients. Neurol Med Chir (Tokyo) 39:226-229, 1999.

28) Sakata K, Al-Mefty O, Yamamoto I: Venous consideration in petrosal approach: Microsurgical anatomy of the temporal bridging vein. Neurosurgery $47: 153-160,2000$.

29) Samii M, Ammirati M, Mahran A, Bini W, Sepehrnia A : Surgery of petroclival meningiomas : Report of 24 cases. Neurosurgery 24: 12-17, 1989.

30) Samii M, Tatagiba M, Carvalho GA: Resection of large petroclival meningiomas by the simple retrosigmoid route. $J$ neurosurg Sci 6:27-30, 1999.

31) Samii M, Tatagiba M, Carvalho GA: Retrosigmoid intradural surameatal approach to Meckel's cave and the middle fossa: Surgical technique and outcome. J Neurosurg 92 : 235-241, 2000.

32) Seonane E, Rhoton AL Jr: Suprameatal extension of the retrosigmoid approach: Microsurgical anatomy. Neurosur- gery 44:553-560, 1999.

33）塩原隆造：小脳橋角部腫瘍に対する transpetrosal approach の微小脳神経外科解剖. 山浦 晶編 : 顕微鏡下 手術のための脳神経外科解剖 4. 東京, サイメッド・パ ブリケーションズ, pp.71-78, 1992.

34) Shiobara R, Ohira T, Kanzaki J, Toya S: A modified extended middle cranial fossa approach for acoustic nerve tumors. Results of 125 operations. J Neurosurg 68 : 358$365,1988$.

35) Sugita K, Kobayashi S, Yokoo A: Preservation of large bridging veins during brain retraction: Technical note. $J$ Neurosurg 57:856-858, 1982.

36）田草川 豊：三叉神経痛に対する Microvascular Decompression一広い手術操作空間を得る工夫一. 脳外誌 17 ： 199-204, 2008.

37) Tsukamoto H, Matsushima T, Fujiwara S, Fukui M : Peduncular hallucinosis following microvascular decompression for trigeminal neuralgia : case report. Surg Neurol $\mathbf{4 0}$ : 31-34, 1993.

38）山本 茂,白馬 明：経乳様突起到達法.白馬 明, 山浦 晶編 : 頭蓋底の外科. 東京, 医学書院, 1994, pp104-113.

39）吉田一成,河瀬 斌：Anterior Transpetrosal Approach. 松 野治雄編：顕微鏡下手術のための脳神経外科解剖XI．東 京, サイメッド・パブリケーションズ, 1999, pp.178-186.

40) Yoshida K, Kawase $T$ : Trigeminal neurinomas extending into multiple fossae: surgical methods and review of the literature. J Neurosurg 91:202-211, 1999.

Petroclival Region Tumor の手術と静眽

$\begin{array}{llrl}\text { 松島 } & \text { 俊夫 } & \text { 増岡 } & \text { 淳 } \\ \text { 井上 河島 雅到 }\end{array}$

Petroclival region tumor は正中深部に存在し，しかも腫瘍によっては小脳テント上下に存在するた め, 到達困難で手術が最も難しい腫瘍の一つである. われわれはこの部の畽瘍に対して症例により後 方経錐体法と外側後頭下開頭法を使い分けてきた. Petroclival region tumor への外側後頭下開頭法は, infratentorial lateral supracerebellar approach で，必要があれば小脳テントを切開し transtentorial approach を下方より追加することができる.このアプローチにおいて障害物の一つは superior petrosal vein (SPV) である. 後方経錐体法の場合，SPVはそれほど問題とならないが, vein of Labbé, 側頭葉下面の架橋静脈, テント切痕部への架橋静脈，テント静脈洞などが障害物となる. 本稿では infratentorial lateral supracerebellar transtentorial approach ならびに後方経錐体法の基本的手術手技 と小脳テント切痕部近傍の深部静脈の解剖について解説した. 